greatest hope of solving the world's problems and industry's problems. It has always been true that the things men live with largely determine the ideas men live by, and the kind of economy and the kind of government we enjoy are determined mainly by the things industry produces and the use that is made of them. This is not a materialistic doctrine, he said, for there is also a spiritual factor which is possibly the most important, and research itself contributes to this: besides its creative and constructive value, its contribution to economic security and thus to peace, and its challenge to competition, research contributes such values as objectivity and the patient, persistent search for the truth to the partnership on which industrial progress depends. Business, for its part, should contribute understanding and encouragement, as well as finance, and General Sarnoff was emphatic that industry rather than government should bear a main responsibility for the finance of research: government control might destroy the very qualities that enable the research worker to make his most important contribution to society. The future of the Stanford Research Institute, he said, is bright because it recognizes the dependence of applied research on the new knowledge revealed through basic research and maintains a close relation with other research centres throughout the United States.

Some details of the growth of the Stanford Research Institute since 1947 and of its work during 1951 are given in the fifth annual report of the Institute*, which includes a quotation from General Sarnoff's address. Its full-time staff (scientific, technical, managerial and service) increased by 65 per cent during 1951 to 425 , and, of the 214 projects on which the Institute was engaged, 184 were for commercial and government sponsors. Expenditure totalled $3 \cdot 6$ million dollars, compared with 1.99 million dollars in 1950, and close affiliation with Stanford University continued to be a vital factor in the development of the Institute.

In the Department of Chemistry, which with a staff of more than seventy-five now conducts research costing 1.2 million dollars annually, among the research projects mentioned in this report are those on the development of a method for the continuous large-scale separation of ionic substances, the efflorescence of latex paint films, the evaluation of ceramic materials, the oxidation of xylenes and the industrial uses of coconut oil derivatives. During the past four and a half years the Air Research Laboratories of the Institute have spent more than 2 million dollars in studying air-pollution problems in different parts of the United States. Besides developing much special equipment, the laboratories have intensified efforts to spread information on airpollution dangers and their prevention. In the Applied Physics Department an ion-scattering analyser is under construction, and the radiation laboratory is attacking the primary objectives of developing processes using large quantities of radioactive material as a source of penetrating gamma-rays and providing all branches of the Institute with staff and facilities for experimental work with radioisotopes. The Division of Geophysics and Geology is continuing its programme on the development of the Poulter seismic method of surveying underground structures and is undertaking seismic exploration in Western Texas.

* Stanford Research Institute: Annual Report, 1951. Pp. 48. From the Institute, Stanford, California; 1 952 .)
A staff of 125 is engaged on engineering research, and projects specifically mentioned in the report include studies on aircraft antenna theory and design, automatic assembly techniques for miniature electronic equipment, the development of the three-colour picture-tube system of television based on the Geer principle, and the response testing of pulse transformers. The Department of Industrial Economics, with a staff of sixty-five, has conducted a technoeconomic survey of the hard-board industry ; economic studies of Cuba and of a proposed crude-oil pipe-line from Edmonton, Alberta, to Vancouver, British Columbia; an investigation, for the United States Atomic Energy Commission, of the technological and economic questions involved in the industrial use of radioactive fission products ; and a co-operative survey, with the South-west Research Institute, the Armour Research Foundation and the Battelle Memorial Institute, of fundamental and applied research activities in Western Germany. Biological research continued to expand; and in the biochemical field particular attention was given to problems of nutrition, toxicity, cancer and the effects of radiation, including studies of the effect of fluoride intake on the general health of cattle, the toxicity of chemicals used to prevent mould growth in eitrus products, and the effects of X-radiation and radioactive isotopes on normal tissue and tumours.

The Institute continued to publish its "Chemical and Economics "Handbook", and investigations sponsored by the Institute itself included a fundamental study of chemical reactions in aerosol systems, the design of a special still-head which eliminates the need for a separate receiver changer, a study of Goetz molecular filter membranes for the removal of pyrogens from aqueous media, the development of a fractionating column efficient at low pressures, the development and application of paper-chromatographic techniques, the reactions occurring between polymer molecules and the free radicals present during the formation of vinyl polymers, and a study of the applications in analytical chemistry of ion-exchange resins.

\section{HOUSING IN THE U.S.S.R.}

$A$

BRIEF survey of housing development in the U.S.S.R. from 1917 until the present day by Dr. E. M. Chossudovsky (Housing and Town and Country Planning, Bull. 5, United Nations Publication) shows that the material difficulties with which the Government has had to deal have been formidable. The housing resources taken over by the Soviet authorities after the Revolution were both quantitatively inadequate and in appallingly poor condition. Very little new construction took place until the late 1920 's, and it was not always possible to devote sufficient attention to repair work, so that the prerevolutionary level of housing was restored less quickly than that of the other branches of the economy.

With the beginning of the era of the Five Year Plans (1928-29) the situation improved; altogether before the Second World War about 113 million square metres (approximately 1,216 million square feet) of urban living space had been constructed since the inception of the Soviet regime. Much was done by way of improving the quality of housing, developing and improving municipal services and providing communal buildings of all kinds. 
Two hundred new cities were built between 1926 and 1939 , in conformity with the changing character and distribution of the population and the development of the country's eastern areas. Yet, despite all this progress, it proved impossible to bridge the gap between population growth and housing; housing construction lagged behind the rate of industrialization, and the urban population increased at an exceptionally rapid rate. Further, much of the pre-revolutionary housing proved to be beyond repair and had to be scrapped, thus slowing down the net growth of the total housing fund.

The war-time destruction of housing amounting to some 30 per cent of the total amount of urban housing, and the extensive and frequently complete destruction of rural housing proved a serious setback. The over-fulfilment of the total urban housing programme of the post-war Five-Year Plan has, however, more than offset the tremendous losses and led to a far-reaching, even revolutionary, modernization of the building industry (especially in the application of express and even-flow methods of erecting houses), which should make it possible to step up housing construction in subsequent five-year plans to a marked extent. The pace of the country's housebuilding has been appreciably increased by the financial and material assistance accorded to individual house-building by the authorities.

In the present stringent housing situation, the Government has controlled the distribution of available housing resources, taking into consideration the priority claims of ex-servicemen, the dependants of war casualties and invalids, the partisans and their families. The relationship between work (type, quantity and quality) and the allocation of limited housing resources, already recognized before the War, has now been further strengthened; it is possible to ensure that the housing requirements of such key workers as the miners are promptly met. Special housing facilities also are provided to meet the needs of workers who settle in newly developed regions. Housing is thus regarded as one of the instruments for increasing the productivity of labour and building up permanent staffs in industry.

\section{MUSEUMS ASSOCIATION ANNUAL CONFERENCE IN OXFORD}

$\mathrm{T}$ HE fifty-eighth conference of the Museums Association was held at Oxford during July 21-25 under the presidency of Mr. S. D. Cleveland, director of the City Art Gallery, Manchester, and was attended by more than three hundred and fifty delegates from both national and provincial museums. This was the third occasion on which the Association has visited Oxford, the previous time being in 1919 .

In his presidential address, on "The Inevitability of Museums", Mr. Cleveland stated that it is necessary to correct a prevailing misconception by which museums are regarded as educational institutions only. It is true, he said, that education must be an integral part of their work; but it should take its place with the other functions of collection, conservation, interpretation, research and service to the community.

Dr. H. J. Plenderleith, keeper of the Research Laboratory at the British Museum, in a paper on "Fakes and Forgeries", described his subject as a very human study in which the man of science can help the scholar. In fact, the intimate co-operation of these two is essential, and there must be complete sympathy with each other's aims and methods. He enumerated some of the physical and chemical methods used at the British Museum, and spoke of the difficulties encountered when it is necessary to form an opinion without even marking the object.

Sir Philip Hendy, director of the National Gallery, stressed that the primary function of museums and art galleries is to be a Temple of the Muses and that no secondary function should be allowed in any way to interfere. Museums are guardians of $\mathbf{a}$ high standard of quality. He spoke in favour of the production of good reproductions of first-class paintings and pleaded for a more liberal interpretation of the function of art galleries.

In a session of a rather more domestic nature, the story of museums in Oxford was told by the five directors concerned. In all the papers, and in the subsequent discussion, it was apparent that the pendulum is swinging once again with regard to the amount of material that should be displayed in museums. From showing everything, the general tendency a few years ago was to show almost nothing. Now a compromise has been made, and it is realized that the arrangement as seen in the windows of the departmental stores is not the ideal prototype for museum cases. The apathy of the University of Oxford towards its museums was commented upon by several speakers, and the hope expressed that one result of the conference on the part of the University would be an increased interest in the value of its great collections. The hope was also expressed that the City of Oxford would consider the establishment of a museum to illustrate its own history.

Speaking on "Changing Fashions in Museum "Teaching", Mr. Peter Floud, of the Victoria and Albert Museum, London, emphasized the value of making use of the galleries in addition to the children's rooms which are now established in so many museums. There is a distinct danger that museum work may become simply an extra-mural function of the school. He also dealt with the three-dimensional didactic displays which produce indirect museum teaching, and illustrated his remarks with actual examples of exhibition work. Dr. C. H. V. Sutherland, of the Ashmolean Museum, Oxford, said that there is a real public interest in numismatics and that museums should make every effort to satisfy this. He agreed that there are few trained numismatists in Great Britain, and stated that a British association of the various numismatic societies would probably be formed in the near future. He hoped that the Museums Association would co-operate in this matter. Mr. J. W. Y. Higgs, of the Museum of English Life, Reading, described this new museum of English rural life and stated how, as a nation, England is deeply conscious of its rural history.

At the annual general meeting of the Association, held during the conference, a protest was made against the cuts in Treasury grants to national museums and art galleries. The Association decided to send to the Chancellor of the Exchequer a resolution deploring the cuts as "gravely endangering the safety of the national treasures and curtailing the educational, æsthetic and scientific facilities provided".

Dr. F. J. North, of the National Musoum of Wales, Cardiff, was elected president for the Conference in 1953, which will be held in York during June 22-26. 